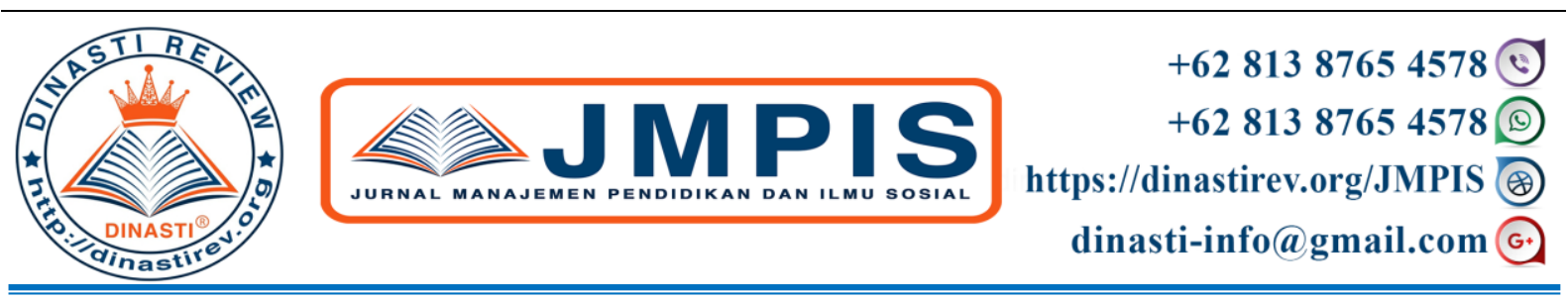

\title{
PERLINDUNGAN SOSIAL MELALUI KEBIJAKAN PROGRAM BANTUAN LANGSUNG TUNAI (BLT) DI ERA PANDEMI COVID-19: TINJAUAN PERSPEKTIF EKONOMI DAN SOSIAL
}

\author{
Baso Iping \\ Universitas Ekasakti, Padang, Indonesia
}

\begin{tabular}{|c|c|}
\hline $\begin{array}{l}\text { ARTICLE INFORMATION } \\
\text { Received: } 27 \text { Juni } 2020 \\
\text { Revised: } 30 \text { Juni } 2020 \\
\text { Issued: 19 Juli } 2020 \\
\text { Corresponding author: } \\
\text { Baso Iping } \\
\text { E-mail: } \\
\text { baso_ifing@ymail.com }\end{array}$ & $\begin{array}{l}\text { Abstrak: Penelitian ini bertujuan untuk menganalisis } \\
\text { kebijakan perlindungan sosial di Indonesia, } \\
\text { perlindungan sosial melalui pemberian BLT di masa } \\
\text { pandemi covid-19 serta dampak yang ditimbulkan dari } \\
\text { segi ekonomi dan sosial. Metode yang digunakan } \\
\text { adalah metode deksriptif dengan pengumpulan data } \\
\text { melalui library studies (studi kepustakaan), di mana } \\
\text { penulis melakukan penelusuran terhadap literatur } \\
\text { kemudian melakukan penelaahan. Setelah itu, dianalisis } \\
\text { dalam bentuk deskriptif kualitatif. Hasil yang diperoleh } \\
\text { adalah bahwa: Pertama, di Indonesia, pelaksanaan } \\
\text { sistem perlindungan sosial telah dilakukan melalui } \\
\text { berbagai program dan telah berjalan lama. Program- } \\
\text { program perlindungan sosial tersebut telah dilaksanakan } \\
\text { sejak masa pemerintahan orde baru. Kedua, pada masa } \\
\text { pandemic covid-19 pemerintah memberikan bantuan } \\
\text { dalam bentuk tunai yang ditujukan kepada kelompok } \\
\text { masyarakat paling terdampak pandemi COVID-19, } \\
\text { meliputi masyarakat miskin, pekerja informal serta } \\
\text { pelaku usaha transportasi daring. Ketiga, secara } \\
\text { ekonomi, pemberian BLT di satu sisi memberikan } \\
\text { dampak yang sangat signifikan untuk mempertahankan } \\
\text { daya beli dan kepada kelompok pelaku usaha untuk } \\
\text { kelangsungan usaha dan meminimalkan } \\
\text { dampak pemutusan hubungan kerja (PHK), namun dari } \\
\text { segi sosial dapat memicu gejolak berupa konflik serta } \\
\text { timbulnya korupsi. } \\
\text { Kata Kunci: Perlindungan Sosial, Bantuan Langsung } \\
\text { Tunai, Pandemi, Covid-19 }\end{array}$ \\
\hline
\end{tabular}

\section{PENDAHULUAN}

Tujuan negara Indonesia tercantum dalam pembukaan UUD Negara Republik Indonesia Tahun 1945 alinea ke-4 (empat) yang salah satunya berbunyi memajukan kesejahteraan umum. Maksud dari memajukan kesejahteraan umum di sini adalah untuk meningkatkan kesejahteraan melalui pemberian peran yang lebih penting kepada negara 
dalam memberikan pelayanan sosial secara universal dan komprehensif kepada warganya yang mencakup jaminan sosial (baik berbentuk bantuan sosial dan asuransi sosial), maupun jaring pengaman sosial (social safety nets).

Dalam sistem negara kesejahteraan, jaminan sosial merupakan sektor kunci yang didasarkan bahwa negara harus berusaha serta mampu menjamin adanya jaring pengaman pendaatan bagi warganya yang tidak memiliki sumber pendapatan untuk memenuhi kebutuhan hidunya.

Di Indonesia, konsep tentang jaminan sosial telah diatur dalam berbagai peraturan perundang-undangan. Dalam Undang Undang Dasar Negara Republik Indonesia Tahun 1945 pada Bab XIV dengan judul Perekonomian Nasional dan Kesejahteraan Sosial, yang terdiri dari dua pasal, yaitu Pasal 33 dan Pasal 34. Pasal 33 lebih menekankan pada Perekonomian Nasional, sedangkan Pasal 34 lebih menekankan pada kesejahteraan Sosial. Pasal 34 ayat (1) menyatakan bahwa, "fakir miskin dan anak-anak yang terlantar dipelihara oleh negara". Kemudian dalam Pasal 34 ayat (2) dinyatakan bahwa: "Negara mengembangkan sistem jaminan sosial bagi seluruh rakyat dan memberdayakan masyarakat yang lemah dan tidak mampu sesuai dengan martabat kemanusiaan".

Guna merealisasikan amanat dari Pasal 34 UUD NRI Tahun 1945, maka dari era orde lama hingga orde baru, dan saat ini telah bermunculan berbagai produk Undang-Undang yang mengatur tentang kesejahteraan sosial, di antaranya pada masa pemerintahan Presiden Susilo Bambang Yudoyono telah lahir Undang-Undang RI Nomor 40 Tahun 2004 tentang Sistem Jaminan Sosial Nasional. Pada tahun 2009 ditetapkan Undang-Undang RI Nomor 11 Tahun 2009 tentang Kesejahteraan Sosial. Selanjutnya pada tahun 2011 lahir pula Undang-Undang RI Nomor 13 Tahun 2011 tentang Penanganan Fakir Miskin. Langkah nyata tersebut melalui penerbitan kebijakan pemerintah melalui dokumen peraturan perundang-undangan yang mendukung pengentasan kemiskinan yang kemudian dituangkan ke dalam program-program pengentasan kemiskinan.

Pada masa pemerintahan Presiden Soesilo Bambang Yudhoyono dikeluarkan kebijakan Bantuan Langsung Tunai (BLT) tidak bersyarat pada Oktober tahun 2005 sampai Desember 2006 dengan target 19,2 juta keluarga miskin sebagai dampak dari kenaikan harga minyak dunia pada tahun 2004. Lalu, karena harga minyak dunia kembali naik, pada 2008 pemerintah kembali melaksanakan Program Bantuan Langsung Tunai (BLT) seperti pada 2005. Langkah ini ditempuh sebagai upaya pengentasan kemiskinan.

Pada masa pemerintahan Presiden Joko Widodo - Jusuf Kalla juga mengeluarkan kebijakan dengan memperbaiki program perlindungan sosial. Strategi tersebut sebagai langkah penanggulangan kemiskinan. Prinsip pertama adalah memperbaiki dan mengembangkan sistem perlindungan sosial bagi penduduk miskin dan rentan. Sistem perlindungan sosial dimaksudkan untuk membantu individu dan masyarakat menghadapi goncangan-goncangan (shocks) dalam hidup, seperti jatuh sakit, kematian anggota keluarga, kehilangan pekerjaan, ditimpa bencana atau bencana alam, dan sebagainya. Sistem perlindungan sosial yang efektif akan mengantisipasi agar seseorang atau masyarakat yang mengalami goncangan tidak sampai jatuh miskin.

Berdasarkan kebijakan pemerintah yang dituangkan di dalam peraturan perundangundangan diketahui bahwa pada masa pemerintahan Joko Widodo-Jusuf Kalla, pemerintah mengeluarkan Peraturan Presiden Nomor 166 Tahun 2014 tentang Program Percepatan 
Penanggulangan Kemiskinan. Dalam Peraturan Presiden ini disebutkan bahwa untuk mempercepat penanggulangan kemiskinan, pemerintah menetapkan program perlindungan sosial yang meliputi: (a) Program Simpanan Keluarga Sejahtera; (b) Program Indonesia Pintar; (c) Program Indonesia Sehat (Murdiyana dan Mulyana, 2017:87).

Kebijakan penanggulangan kemiskinan berlanjut di periode kedua kepemimpinan Joko Widodo. Salah satu bentuk perlindungan sosial adalah melalui pemberian Bantuan Langsung Tunai kepada masyarakat miskin di masa pandemi wabah corona yang dikenal dengan nama covid-19. Pandemi covid-19 memberikan dampak terutama sektor ekonomi. Banyak perusahaan terpaksa gulung tikar karena tidak lagi bisa berproduksi, ratusan ribu karyawan kena Pemutusan Hubungan Kerja (PHK) dari tempat mereka mencari sesuap nasi. Alhasil, masyarakat miskin semakin meningkat sehingga sangat mengharapkan uluran tangan dari pemerintah.

Melalui penelitian ini mencoba menganalisis mengenai kebijakan perlindungan sosial di Indonesia, perlindungan sosial melalui pemberian BLT di masa pandemi covid-19 serta dampak yang ditimbulkan dari segi ekonomi dan sosial, sehingga untuk selanjutnya bisa menjadi bahan pelajaran dan perbandingan untuk pemberian BLT di masa-masa yang akan datang.

\section{METODE PENELITIAN}

Metode yang digunakan dalam penelitian ini adalah metode deksriptif. Metode pengumpulan data yang digunakan melalui library studies (studi kepustakaan), di mana penulis melakukan penelusuran terhadap literatur kemudian melakukan penelaahan. Setelah itu, dianalisis dalam bentuk deskriptif kualitatif.

\section{HASIL DAN PEMBAHASAN \\ Perlindungan Sosial di Indonesia}

Perlindungan sosial merupakan aspek yang tidak terpisahkan dalam proses pembangunan di Indonesia. Cita-cita bangsa Indonesia akan sistem perlindungan sosial telah diamanatkan dalam Undang-Undang Dasar (UUD) 1945 sebagai landasan konstitusi Negara. Perlindungan sosial di Indonesia telah mengalami perkembangan yang cukup panjang. Saat ini, tonggak dari sistem perlindungan sosial telah diperkuat melalui lahirnya Sistem Jaminan Sosial Nasional (SJSN). Sistem perlindungan sosial di Indonesia akan terus mengalami pengembangan untuk menyediakan perlindungan dan jaminan keterpenuhan kebutuhan dasar hidup yang layak, terutama bagi penduduk miskin dan rentan.

Perlindungan sosial merupakan sebuah aspek yang tidak terpisahkan dalam proses pembangunan serta pengentasan kemiskinan dan pengurangan kesenjangan dalam sebuah negara. Cita-cita bangsa Indonesia akan sistem perlindungan sosial telah diamanatkan dalam Undang-Undang Dasar (UUD) 1945 sebagai landasan konstitusi negara. Pembukaan UUD 1945 mengamanatkan bahwa pemerintah harus melindungi segenap bangsa dan seluruh tumpah darah, memajukan kesejahteraan umum, serta mencerdaskan kehidupan bangsa.

Menurut Pasal 34 UUD 1945 juga mengamanatkan bahwa fakir miskin dan anak telantar dipelihara oleh negara dan negara wajib mengembangkan sistem perlindungan dan jaminan sosial yang bersifat nasional. Suharto (2008) mendefinisikan perlindungan sosial sebagai segala inisiatif baik yang dilakukan pemerintah, swasta, atau masyarakat untuk 
mewujudkan transfer pendapatan atau konsumsi pada penduduk miskin, melindungi kelompok rentan terhadap risiko penghidupan, serta meningkatkan status sosial kelompokkelompok yang terpinggirkan.

Di Indonesia, pelaksanaan sistem perlindungan sosial telah dilakukan melalui berbagai program dan telah berjalan lama. Program-program perlindungan sosial tersebut telah dilaksanakan sejak masa pemerintahan orde baru. Meski begitu, program-program tersebut belum dirancang secara eksplisit dibawah sebuah sistem perlindungan sosial. Sistem perlindungan sosial Indonesia diarahkan untuk membantu mewujudkan pembangunan yang lebih merata dan berkeadilan. Hingga kini, sistem perlindungan sosial di Indonesia telah dituliskan dalam berbagai rencana dan dokumen strategis seperti Master Plan Percepatan Pengurangan Kemiskinan di Indonesia (MP3KI) serta Social Protection Floor (Landasan Perlindungan Sosial). Rancangan dari berbagai pihak tersebut penting untuk diselaraskan dengan dokumen perencanaan pemerintah dalam sebuah kerangka yang menjadi landasan pelaksanaan program selama periode pembangunan yang akan berjalan.

Kebijakan perlindungan sosial di Indonesia harus bergerak sejalan dengan kondisi demografi masyarakat yang terus berubah. Perubahan demografi yang terjadi dapat mencakup perubahan pada struktur usia, jenis kelamin, etnis, jumlah penduduk, serta berbagai karakteristik lainnya. Salah satu isu perubahan demografi yang perlu diperhatikan adalah bonus demografi, yakni kondisi di mana rasio ketergantungan mencapai titik terendahnya. Struktur penduduk di Indonesia diprediksi akan didominasi oleh penduduk berusia produktif dengan proporsi penduduk usia produktif dengan nonproduktif sebesar 40 berbanding 100 di tahun 2020-2030. Rendahnya angka ketergantungan membuat penduduk usia produktif akan berperan lebih banyak dalam kegiatan perekonomian. Oleh sebab itu, kebijakan perlindungan sosial dapat menyasar penduduk berusia produktif dan penduduk lanjut usia. Program perlindungan sosial mencakup kerentanan baik untuk usia produktif maupun usia nonproduktif, dimana kerentanan-kerentanan tersebut akan dijelaskan lebih lanjut pada sub-bab berikutnya mengenai risiko kerentanan berdasarkan siklus hidup.

Kebijakan perlindungan sosial di Indonesia harus terus disesuaikan dengan perubahan kondisi sosial penduduk. Kondisi sosial penduduk dapat terus mengalami perubahan, begitu juga dengan penduduk yang menjadi target dari program perlindungan sosial. Dalam selang waktu tertentu, terdapat kemungkinan bahwa terdapat penduduk yang keluar dari kriteriakriteria sosial sebagai penerima manfaat program serta terdapat pula penduduk yang jatuh ke dalam kriteria sosial penerima manfaat program. Jika penentuan penerima program perlindungan sosial tidak terus disesuaikan dengan kondisi yang berkembang, inclusion dan exclusion error pada program perlindungan sosial akan terjadi.

Kebijakan perlindungan sosial di Indonesia juga harus memperhatikan perubahan kondisi ekonomi. Kebijakan perlindungan sosial telah dirancang sebagai salah satu instrumen untuk melindungi segenap masyarakat dari berbagai jenis guncangan, salah satunya dari guncangan ekonomi. Sebagai sebuah negara berkembang, Indonesia dengan performa pertumbuhan ekonomi yang baik belum dapat lepas dari risiko guncangan ekonomi. Krisis ekonomi tahun 1997-1998 dapat menjadi contoh dari kebutuhan Indonesia akan sebuah sistem perlindungan sosial yang kuat. Dengan segala risiko dan potensi perubahan kondisi ekonomi, kebijakan perlindungan sosial pada masa mendatang hendaknya dapat menjadi 
$\overline{\text { instrumen kuat untuk melindungi segenap warga negara dari kerentanan akibat guncangan }}$ yang terjadi.

Berdasarkan Undang-Undang Nomor 25 Tahun 2004 tentang Sistem Perencanaan Pembangunan Nasional, perencanaan pembangunan di Indonesia dibagi ke dalam 3 (tiga) tahap, yakni perencanaan pembangunan jangka panjang, perencanaan pembangunan jangka menengah, dan perencanaan pembangunan jangka pendek. Pembangunan jangka panjang dirumuskan dalam dokumen Rencana Pembangunan Jangka Panjang (RPJPN) tahun 20052025.Pembangunan jangka menengah dirumuskan dalam Rencana Pembangunan Jangka Menengah (RPJMN) yang disusun setiap lima tahun selama periode pembangunan jangka panjang. Pembangunan jangka pendek dirumuskan dalam Rencana Kerja Pemerintah yang disusun setiap tahunnya. Saat ini, Indonesia akan memasuki periode pelaksanaan RPJMN III (2015-2019). Berangkat dari hal tersebut, identifikasi potensi serta perancangan arah pengembangan sistem perlindungan sosial di Indonesia sangatlah penting untuk terus dilakukan.

Program-program perlindungan sosial di Indonesia sampai saat ini masih dapat terus dikembangkan. Selama ini, banyak program perlindungan sosial di Indonesia yang masih dilaksanakan secara terpisah-pisah. Lahirnya Undang-Undang Nomor 40 Tahun 2004 tentang Sistem Jaminan Sosial Nasional yang diikuti lahirnya Undang-Undang Nomor 24 Tahun 2011 tentang Badan Penyelenggara Jaminan Sosial menjadi salah satu momen penting dalam perjalanan sistem perlindungan sosial di Indonesia. Undang-Undang tersebut mengatur sebuah sistem jaminan sosial yang lebih terpadu untuk dilaksanakan pada masa mendatang. Layaknya program jaminan sosial, program bantuan sosial di Indonesia juga masih membutuhkan pengembangan dan transformasi. Dengan pengembangan dan transformasi pada program jaminan serta bantuan sosial, diharapkan pengurangan angka kemiskinan, pemenuhan hak-hak dasar, hingga perlindungan bagi penduduk atas setiap guncangan sosial ekonomi di Indonesia dapat diwujudkan.

\section{Perlindungan Sosial Melalui Pemberian BLT di Masa Pandemi Covid-19}

Pandemi Covid-19 telah berdampak secara sistemik dan multidimensional kepada hampir semua aspek kehidupan. Dampak yang paling menonjol adalah dampak setelah dampak kesehatan adalah dampak ekonomi dan sosial.

Menindaklanjuti dampak yang ditimbulkan oleh segi ekonomi terhadap menurunnya pendapatan masyarakat, maka salah satu kebijakan yang dikeluarkan oleh pemerintah berupa pemberian perlindungan sosial dalam bentuk pemberian Bantuan Langsung Tuna (BLT) pada masa pandemi covid-19. Bantuan langsung tunai (BLT) diberikan kepada kelompok masyarakat paling terdampak pandemi COVID-19, meliputi masyarakat miskin, pekerja informal serta pelaku usaha transportasi daring.

Menurut Harian Republika (2020), Bantuan Langsung Tunai (BLT) diberikan kepada 29,3 juta masyarakat yang masuk dalam 40 persen rumah tangga termiskin. Bantuan sosial ini untuk menjaga daya beli kelompok masyarakat yang dianggap paling terdampak wabah virus corona baru (Covid-19).

Program perlindungan sosial yang diluncurkan oleh pemerintah guna menghadapi dampak sosial ekonomi pandemi virus corona secara garis besar dapat dianalisa dengan menggunakan pendekatan "prakorona dan era pandemi korona". Perlu diketahui bahwa 
$\overline{\text { sebelum terjadi pandemi virus korona, pemerintah telah menjalankan berbagai jenis program }}$ perlindungan sosial yakni PKH dan BPNT. Untuk menghadapi dampak pandemi, pemerintah melakukan peningkatan dari sisi jumlah penerima manfaat dan jumlah nominal PKH dan BPNT agar fit dengan dampak pandemi virus korona. Sementara, program Kartu Prakerja merupakan program unggulan dari pemerintahan Joko Widodo periode 2019-2024. Program perlindungan sosial yang baru dan ditujukan secara khusus untuk "bantalan" pada masa pandemi virus korona adalah Bantuan Tarif Listrik, Keringanan Pembayaran Kredit bagi Sektor Informal dan Alokasi Anggaran Cadangan untuk pengadaan kebutuhan bahan pokok.

Menurut data dari Kemendes, dana desa yang dialihkan untuk BLT tersebut sekitar 31 persen dari total Rp.72 triliun atau sebesar Rp.22,4 triliun. Program itu akan disalurkan bagi 12,3 juta kepala keluarga (KK) terdampak Covid-19 dan diserahkan oleh kepala desa serta perangkat desa. Alokasi pemberian BLT dibagi dalam tiga tingkatan dengan merujuk pada besaran dana desa. Pertama, desa yang memiliki anggaran kurang dari Rp.800 juta, BLT dialokasikan sebesar 25 persen. Kedua, desa yang memiliki anggaran Rp800 juta hingga Rp1,2 miliar mengalokasikan BLT sebesar 30 persen. Dan ketiga adalah desa dengan anggaran di atas Rp1,2 miliar BLT yang dialokasikan 35 persen. Untuk itu, perlu ada revisi APDes dengan merujuk pada Permendagri Nomor 69 Tahun 2018. Dana desa akan fokus ketiga hal, yaitu penanganan Covid-19, Program Padat Karya Tunai Desa dan BLT.

Dalam konteks pandemi Covid-19, BLT diberikan kepada masyarakat miskin untuk mempertahankan daya beli dan kepada kelompok pelaku usaha untuk kelangsungan usaha dan meminimalkan dampak pemutusan hubungan kerja (PHK). Dengan mempertimbangkan beragamnya karakteristik warga miskin dan rentan di Indonesia, pemerintah tidak bisa menerapkan satu mekanisme penetapan sasaran dan penyaluran BLT. Besaran BLT yang diberikan sebesar Rp. 600.000 per bulan. Kebijakan bantuan tunai ini dilakukan untuk tetap menjaga daya beli masyarakat miskin saat pandemi wabah Virus Corona (Covid-19).

Penyaluran BLT ini diberikan selama 3 (tiga) bulan dari April hingga Juni. Syarat penerimanya adalah keluarga miskin yang bukan termasuk penerima Program Keluarga Harapan (PKH), tidak memperoleh Kartu Sembako dan Kartu Prakerja. Para penerima BLT ini didasarkan dari Data Terpadu Kesejahteraan Sosial (DTKS). Ketentuan mengenai mekanisme pendataan, penetapan data penerima manfaat, dan pelaksanaan pemberian BLT Desa dilakukan sesuai ketentuan Menteri Desa PDTT. BLT dianggarkan dalam APBDesa maksimal sebesar 35 persen dari dana desa atau lebih dengan persetujuan pemerintah kabupaten/kotamadya. Penyaluran dana desa juga dipermudah melalui penyederhanaan dokumen dan penyaluran yang diupayakan agar lebih cepat. Kepala desa merupakan pihak yang bertanggung jawab atas penggunaan, penyaluran hingga pertanggungjawaban BLT Desa. BLT dana desa merupakan program prioritas yang harus dianggarkan oleh pemerintah desa. Jika pemerintah desa tidak menganggarkan BLT dana desa, pemerintah desa akan dikenakan sanksi mulai dari pemotongan sebesar 50 persen untuk penyaluran Dana Desa tahap berikutnya hingga penghentian penyaluran dana desa tahap III. Pendampingan dan pengawasan terhadap pemanfaatan BLT Dana Desa dapat dilakukan oleh Pemerintah Pusat dan Daerah. 


\section{Pemberian BLT Ditinjau dari Segi Ekonomi dan Sosial}

\section{Dampak Ekonomi}

Pandemi Covid-19 secara ekonomi berdampak terhadap kolapsnya dunia usaha, kemiskinan bahkan kelaparan. Secara sosial berpotensi menimbulkan gejolak konflik yang cukup besar, konflik keagamaan dan peribadatan, konflik disharmoni akibat kemiskinan, sampai konflik konfrontatif akibat kebijakan pemerintah yang tidak tepat (Mohamad Ijudin, 2020).

Covid-19 secara nyata telah berdampak terhadap perekonomian di berbagai sektor, yaitu sektor rumah tangga, UMKM, korporasi maupun sektor keuangan baik swasta maupun negara. Selain mengancam kesehatan ribuan, puluhan ribu, bahkan mungkin ratusan ribu warga. Juga jutaan bahkan puluhan atau ratusan juta orang (masih sulit diprediksi) terancam kehilangan pendapatan dan kemampuan memenuhi kebutuhan minimalnya, sehingga terjadi penurunan daya beli masyarakat. Lebih jauh jika tidak mampu ditangani dengan baik maka bukan hanya dampak kemiskinan namun bisa saja dampak kelaparan bagi masyarakat tertentu.

Pandemi virus korona telah berdampak pada menurunnya kemampuan daya beli masyarakat miskin baik di desa maupun di kota. Pekerja informal yang menggantungkan pendapatan harian sangat terpukul dengan adanya kebijakan social-physical distancing dan work from home sebagai salah satu cara menghambat penyebaran virus corona. Dengan skala dan kecepatan penyebarannya, pandemi ini akan berdampak berat pada seluruh aspek kehidupan. Krisis multidimensi diperkirakan akan terjadi. Guna menjaga standar hidup layak dan kemampuan daya beli (purchasing power), maka pemerintah harus mengeluarkan bantuan tunai tanpa syarat (unconditional cash transfer) (Prakarsa Policy Brief, 2020:21).

Melalui Peraturan Pemerintah Pengganti UndangUndang Nomor 1 Tahun 2020 tentang Kebijakan Keuangan Negara dan Stabilitas Sistem Keuangan untuk Penanganan Pandemi Corona Virus Disease 2019 (COVID-19) dan/atau dalam Rangka Menghadapi Ancaman yang Membahayakan Perekonomian Nasional dan/atau Stabilitas Sistem Keuangan, pemerintah Indonesia melakukan upaya penanganan kesehatan, penanganan dampak sosial dan penyelamatan perekonomian nasional. Penanganan kesehatan difokuskan pada upaya penyembuhan pasien corona dengan peningkatan anggaran belanja kesehatan. Agenda penanganan dampak sosial difokuskan pada pelaksanaan jaring pengaman sosial (social safety net). Sedangkan untuk pemulihan perekonomian diarahkan kepada pemberian insentif fiskal, perkreditan dan moneter.

Pemerintah melalui Kementerian Desa, Pembangunan Desa Tertinggal, dan Transmigrasi (Kemendesa PDTT) sejak April sudah mulai mencairkan dana bantuan langsung tunai (BLT) dana desa di seluruh wilayah di Indonesia. Metode pencairannya akan dilakukan bertahap dimulai dari bulan April ini hingga Juni 2020. Pada setiap bulannya setiap kepala keluarga miskin akan mendapatkan jatah masing-masing sebesar Rp.600.000. Jumlah keseluruhan masing-masing penerima BLT akan menerima Rp1,8 juta. Awalnya, pendistribusian ini dengan skenario awal yakni melalui cara nontunai. Namun demikian, karena kondisi yang berbeda di setiap daerah, pendistribusian ada yang menggunakan cara secara langsung, bahkan melalui pintu ke pintu atau door to door, untuk mengurangi kerumunan massa. Ini dilakukan sebagai salah satu cara menghindari 
kerumunan warga serta mendukung program pemerintah dalam memutus mata rantai penyebaran Covid-19 (Agus Triyono, 2020).

Artinya, BLT dana desa dapat diberikan kepada penerima secara nontunai atau transfer perbankan. Alternatif lain jika benar-benar tidak memungkinkan untuk dilakukan dengan cara itu, bantuan juga boleh diberikan secara tunai. Hal yang paling utama adalah dana bantuan itu sampai ke penerima BLT dan bisa dipertanggungjawabkan dengan baik. Seperti diketahui, Kemendesa PDTT menyiapkan anggaran sebesar Rp. 22 triliun dari pagu dana desa 2020 untuk memberikan BLT kepada 12 juta keluarga miskin di berbagai daerah. Para penerima ini merupakan keluarga miskin yang selama ini diperuntukkan bagi mereka yang belum mendapat bantuan dari skema jaminan kesejahteraan sosial lainnya. BLT dana desa diberikan kepada warga kurang mampu di desa yang belum mendapatkan program bantuan pemerintah seperti Program Keluarga Harapan (PKH), Bantuan Pangan Non Tunai (BPNT) dan kartu prakerja. Dana desa diperbantukan untuk memberikan BLT kepada masyarakat miskin atau ekonomi lemah karena pandemi COVID-19 ini. Dengan banyaknya dana bantuan penanggulangan kemiskinan terdampak Covid-19 tentunya ini merupakah upaya dari pemerintah yang cukup melegakan rakyat miskin terdampak, karena secara langsung dapat membantu meringankan beban ekonomi di tengah wabah dahsyat Covid-19.

Pemberian BLT sebagaimana dijelaskan di atas secara umum dapat membantu meringankan ekonomi rumah tangga di masa pandemi, di mana orang dianjurkan orang untuk berdiam di ruman (stay at home). Secara ekonomi, program ini telah membantu perekonomian masyarakat dalam meningkatkan daya beli.

\section{Dampak Sosial}

Selain dampak terhadap perenomian masyarakat, di satu sisi pemberian BLT dari segi sosial telah menimbulkan gejolak berupa konflik. Penyababnya karena pelaksanaan penyaluran di beberapa tempat tidak dilakukan secara baik, adil dan bijaksana, sehingga munculkan gejolak di tengah masyarakat. Secara horizontal akan terjadi kecemburuan dan disharmoni antar masyarakat yang bisa menimbulkan dampak konflik sosial berkepanjangan serta bisa juga akan menimbulkan konflik vertikal karena sebagian masyarakat akan menuduh pemerintahan tidak adil dan tidak benar dalam menyalurkan bantuan tersebut.

Seperti yang terjadi di Desa Air Batu, Kecamatan Renah Pembarap, Kabupaten Merangin, Provinsi Jambi, Selasa 19 Mei 2020, terjadi aksi pembakaran Posko Gugus Tugas Penanganan Covid-19 dan kantor kepala desa. Pemicunya karena penyaluran Bantuan Langsung Tunai (BLT) Covid-19 yang tidak tepat sasaran. BLT yang semestinya diberikan kepada warga sebesar Rp. 600.000/KK, namun kenyataannya BLT yang dialokasikan dari Dana Desa (DD) ada yang tidak tepat sasaran. Warga yang rumahnya tidak layak huni tidak mendapat bantuan, sementara warga yang rumahnya permanen mendaat bantuan. Warga mensinyalir kepala desa pilih kasih, sehingga warga mengamuk.

Konflik yang muncul sebagian besar berupa ketegangan, baik antara non-RTS dan RTS maupun antara non-RTS dan aparat pemerintah. Biasanya ketegangan tersebut dipicu oleh adanya komentar sinis dari non-RTS kepada RTS dan adanya tuduhan nepotisme serta ketidakadilan aparat desa dalam penetapan sasaran penerima BLT. 
Komentar sinis dan tudingan nepotisme ini biasanya muncul dari warga yang merasa lebih miskin dari RTS tetapi tidak menerima BLT.

Selain memicu konflik di tingkat masyarakat, BLT ternyata juga menimbulkan konflik di tingkat keluarga seperti terjadi kasus perkelahian pasangan suami istri karena si suami memakai dana BLT untuk berjudi dan membeli minuman keras. Konflik-konflik keluarga semacam ini sebagian bisa diselesaikan melalui mekanisme penyelesaian internal keluarga dan sebagian harus diselesaikan oleh kepala desa.

Hingga saat penelitian ini dilakukan, pemerintah belum menyusun mekanisme penanganan konflik BLT. Pelaksanaan BLT 2008 yang relatif kondusif bukan disebabkan oleh semakin baiknya mekanisme penyelesaian konflik terkait persoalan BLT atau telah diselesaikannya persoalan yang menjadi pemicu konflik.

Selain dampak terhadap timbulnya konflik, dampak lainnya adalah pemicu timbulnya korupsi. Potensi korupsi antara lain saat pemerintah menggelontarkan dana bantuan untuk warga yang mengalami pelemahan ekonomi karena pandemi Covid-19. Penggelapan dana bantuan. Bisa saja anggaran-anggaran sudah ditransfer bermasalah dalam pelaksanaannya, jumlah bantuan tidak sesuai dengan yang diterima. Akibatnya cukup fatal karena bisa memicu konflik.

Pemberian BLT yang tidak tepat juga bisa juga terjadi pungutan liar, hingga dobel pembiayaan akibat data penerima yang amburadul, BLT Dana desa tersalurkan sesuai peruntukannya adalah menjadi harapan besar. Namun demikian, perlu diingat bahwa dana sebesar itu memiliki celah kerawanan dalam penggunaannya. Beberapa peristiwa di negeri ini banyak bantuan sosial, disalahgunakan oleh oknum yang tidak bertanggungjawab dan rata-rata dilakukan dilakukan oleh oknum pejabat atau mantan pejabat. Sebagai contoh data yang diperoleh dari KPK, kasus penyelewengan dana Bansos yang melibatkan pejabat, seperti mantan gubernur Sumatera Utara, Gatot Pujo Nugroho dihukum 6 (enam) tahun penjara dan denda Rp.200 juta secara sah dan meyakinkan karena terbukti melakukan tindak pidana korupsi dana hibah dan Bansos. Kemudian, mantan sekda kabupaten Tasikmalaya, Abdul Kodir divonis 1 (satu) tahun 4 (empat) bulan pidana terkait korupsi dana bansos juga. Mantan kepala dinas pendapatan Kabupaten Seram Bagian Barat, Maluku, divonis tiga tahun penjara karena korupsi dana bansos. Juga ada mantan ketua DPRD Bengkalis, Riau, Heru Wahyudi, divonis 18 tahun karena korupsi dana bansos. Contoh-contoh tersebut tentu menjadi cermin bahwa BLT dana desa juga memiliki peluang yang sama untuk disalahgunakan oleh oknum tertentu (Agus Triyono, 2020), seperti yang terjadi Desa Banpres, Kecamatan Tuah Negeri, Kabupaten Musirawas, Sumatera Selatan. Seorang kepala dusun dan anggota Badan Permusyawaratan Desa (BPD)nya ditangkap polisi Keduanya diduga telah memotong dana bantuan langsung tunai (BLT) milik warga yang terdampak Covid-19. Mereka ditangkap polisi setelah dilaporkan oleh warga setempat. Kejadian bermula saat Desa Banpres mendapatkan bantuan BLT untuk 91 kepala keluarga (KK). Adapun masing-masing KK mendapatkan Rp 600.000. Namun, setelah uang dibagikan, kedua pelaku mendatangi rumah warga untuk memungut uang dari para penerima bantuan sosial. Masing-masing KK harus memberikan Rp. 200.000 sebagai imbalan untuk kedua pelaku. Kedua tersangka berhasil mengumpulkan uang Rp 3,6 juta dari 18 kepala keluarga. 
Indikasi di atas menunjukkan bahwa pemberian BLT masih terdapat kerawananan. Mulai dari pemicu timbulnya konflik baik secara horizontal maupun vertikal dan bisa juga menjadi bibit-bibit lahirnya tindak pidana korupsi oleh oknum-oknum yang tidak bertanggung jawab.

\section{KESIMPULAN DAN SARAN}

\section{Kesimpulan}

Bedasarkan uraian di atas, maka dapat diberikan kesimpulan sebagai berikut:

1. Di Indonesia, pelaksanaan sistem perlindungan sosial telah dilakukan melalui berbagai program dan telah berjalan lama. Program-program perlindungan sosial tersebut telah dilaksanakan sejak masa pemerintahan orde baru;

2. Pada masa pandemic covid-19 pemerintah memberikan bantuan dalam bentuk tunai yang ditujukan kepada kelompok masyarakat paling terdampak pandemi COVID-19, meliputi masyarakat miskin, pekerja informal serta pelaku usaha transportasi daring.

3. Secara ekonomi, pemberian BLT di satu sisi memberikan dampak yang sangat signifikan untuk mempertahankan daya beli dan kepada kelompok pelaku usaha untuk kelangsungan usaha dan meminimalkan dampak pemutusan hubungan kerja (PHK), namun dari segi sosial dapat memicu gejolak berupa konflik. Konflik sifatnya dapat berupa konflik horizontal karena terjadi kecemburuan dan disharmoni antar masyarakat, serta sifatnya konflik vertikal karena sebagian masyarakat akan menuduh pemerintahan tidak adil dan tidak benar dalam menyalurkan bantuan tersebut. BLT ternyata juga menimbulkan konflik di tingkat keluarga. Selain dampak terhadap timbulnya konflik, dampak lainnya adalah pemicu timbulnya korupsi.

\section{Saran}

Adapun saran terhadap kebijakan pemberian BLT berikutnya secara bijaksana yang bisa dilakukan oleh pemerintah adalah:

1. Melakukan pendataan berdasarkan musyawarah dimulai dari lingkungan RT sampai desa agar data yang diperoleh berdasarkan nilai-nilai kepatutan dan ada aspek kerelaan di tengah-tengah warga;

2. Penyaluran dana bantuan, ketika memang bantuan tersebut tidak mampu mengcover seluruh warga miskin, di sini diperlukan jiwa solidaritas kekeluargaan, persaudaraan, ketetanggaan, dengan penuh kesadaran dan keikhlasan;

3. Utamakan yang menerima bantaun masyarakat yang terlanjur usia ke atas, masyarakat yang statusnya janda yang ditinggal mati oleh suaminya dan tidak memiliki lapangan pekerjaan. Setidaknya langkah tersebut dapat meringankan beban dan tanggungjawab pemerintah terhadap rakyatnya dan dapat mengembalikan kesejatian bangsa Indonesia yang berjiwa kekeluargaan.

\section{DAFTAR RUJUKAN}

Agus Triyono, BLT Dana Desa dan Peluang Korupsi, AYOSEMARANG.COM, Minggu, 03 Mei 2020.

Harian Republika Edisi Sunday, Antisipasi Dampak Covid-19, BLT Segera Datang, Edisi 29 Mar 2020. 
http://www.smeru.or.id/sites/default/files/publication/blt.pdf diakses pada tanggal 10 Juni 2020.

http://m.ayosemarang.com/read/2020/04/23/55823/menegang-adakan-ibadah),diakses tanggal 15 Juni 2020.

Kompas.com, Korupsi BLT Covid-19, Kepala Dusun dan Anggota BPD Ditangkap, Selasa, 2 Juni 2020.

Murdiyana dan Mulyana, "Analisis Kebijakan Pengentasan Kemiskinan di Indonesia”, Jurnal Politik Pemerintahan, Volume 10, No. 1, Agustus 2017.

Mohamad Ijudin, Covid-19, Dampak Ekonomi dan Potensi Konflik Sosial, Pasundannews.COM, Edisi 8 April 2020.

Jambi, Beritasatu.com, Diduga Akibat BLT Salah Sasaran, Warga Merangin Bakar Posko Covid-19, https://www.beritasatu.com/tag/blt), diakses tanggal 20 Mei 2020.

Kementerian Perencanaan Pembangunan Nasional/Badan Perencanaan Pembangunan Nasional, Perlindunan Sosial di Indonesia, Tantangan dan Arah ke Depan, Direktorat Perlindungan dan Kesejahteraan Masyarakat Kementerian Perencanaan Pembangunan Nasional/Badan Perencanaan Pembangunan Nasional, 2014.

Prakarsa Policy Brief, Program Tunai di Era COVID-19: Bantuan Tunai Korona atau Jaminan Penghasilan Semesta, April 2020. 